\title{
Perancangan E-health Kota Cerdas (Studi Kasus : Kota Manado )
}

\author{
Jeklly H. Sambuaga, Yaulie .Deo. Y. Rindengan, Alwin .M. Sambul \\ Teknik Informatika Universitas Sam Ratulangi Manado, Indonesia. \\ Jeklysambuaga@gmail.com,Rindengan@unsrat.ac.id, asambul@gmail.com
}

\begin{abstract}
Abstrak - Smart city merupakan konsep pengembangan, penerapan, dan implementasi teknologi digital untuk menghubungkan, memonitor, dan mengendalikan berbagai sumber daya yang ada dan diaplikasikan pada sebuah wilayah atau kota. Pada beberapa kota maju di Indonesia pun sudah mengadopsi konsep smart city untuk efisiensi pelayanan kepada masyarakat yang berkelanjutan. Kota Manado pun mengharapkan hal yang sama, ditinjau dari kebutuhan akan teknologi informasi mulai dari pemerintahan, penyedia jasa, bahkan seluruh komponen masyarakat.
\end{abstract}

Salah satu bidang pengembangan yang penting untuk dikembangkan adalah bidang kesehatan (health), mulai dari pelayanan pasien untuk rawat jalan, pelayanan pasien untuk rawat inap, pelayanan untuk pengambilan obat, bahkan untuk pengurusan surat-menyurat dari puskesmas ke rumah sakit, rumah sakit ke rumah sakit, dan sebaliknya dalam penerapan pada jasa-jasa kesehatan.

Penelitian ini pun bertujuan untuk merancang model arsitektur dari aplikasi sistem informasi $\boldsymbol{e}$-health Dengan adanya perancangan model arsitektur ini, dapat mempermudah menentukan model dari aplikasi sistem informasi $e$-health, bahkan dapat juga menjadi tolak ukur untuk implementasi di masa yang akan datang. Tentu semuanya dimulai dari peran pemerintah, dalam hal ini pemerintah kota Manado.

Untuk data dan informasi yang berhasil dikumpulkan penulis adalah data proses bisnis setiap penyedia jasa kesehatan dalam bentuk wawancara, kuisioner, dan observasi mulai dari rumah sakit, puskesmas, apotik dan klinik di kota Manado secara langsung. Produk yang dihasilkan dari penelitian ini adalah berupa rancangan model arsitektur $e$-health mulai dari arsitektur data, arsitektur aplikasi serta arsitektur teknologi yang dipresentasikan dalam bentuk gambar dan diagram.

Kata Kunci : E-health, Sistem Informasi, Model Arsitektur, Smart City, Kota Manado

\section{I.PENDAHULUAN}

Kota manado adalah ibu kota dari provinsi Sulawesi utara. Manado terletak di teluk manado, dan dikelilingi oleh daerah pegunungan. kota manado juga adalah kota terbesar kedua setelah makasar di pulau sulawesi. Disamping letak dari kota manado yang terbilang cukup strategis kota manado juga punya daya tarik tersendiri sehingga kota manado menjadi salah satu kota di Indonesia yang terkenal sampai kanca international. Di luar dari itu, layaknya kotakota lain, kota manado juga memiliki sistem operasional di dalamnya. potensi-potensi kota manado terlihat jelas dalam semua bidang mulai dari pemerintahan, pariwisata, pendidikan, kesehatan dan lain-lain.

Dilihat dan dinilai dari itu semuanya gagasan untuk menjadikan kota manado sebagai kota cerdas (smart city) pun muncul mulai dari pemerintah dalam hal ini pemerintah kota manado, dengan visi nya "menjadikan kota manado kota cerdas", dan sampai pada setiap kalangan, (pelajar/mahasiswa, pembisnis, dosen/guru, dll) dengan tujuan agar kota manado bisa memberikan pelayanan yang lebih baik kepada masyarakat nya , juga bisa bersaing dengan kota-kota lain di indonesia bahkan bisa sampai di kanca international. Untuk itu persiapan demi persiapan pun dilakukan diantaranya perbaikan infrastruktur kota, SDM dan lain sebagainya.

Diantara berbagai bidang - bidang yang ingin dikembangkan untuk smart city salah satu bidang penting yang akan di kembangkan adalah bidang kesehatan (health) mulai dari integrasi antara pelaku kesehatan sehingga berujung pada pelayanan kesehatan kepada masyarakat menjadi lebih baik dan lebih efisien. untuk itu perlu di bangun satu sistem informasi yang dapat membantu terwujudnya satu pelayanan yang cepat dan efisien dalam ruang lingkup pelayanan umum (public service) di bidang kesehatan (health). Namun sampai saat ini masih belum ada sistem seperti itu di kota manado. Untuk itu langkah awal yang penting adalah melakukan perancang model arsitektur untuk aplikasi sistem informasi e-health kota manado menuju smart city terlebidahulu, mengingat untuk sistemnya sendiri cukup luas dan belum memungkinkan peneliti untuk membangunnya dalam waktu yang singkat.

\section{LANDASAN TEORI}

\section{A. E-Health}

Secara umum pengertian e-health atau electronic health adalah suatu layanan dalam bentuk aplikasi teknologi informasi dan komunikasi di hubungkan dengan keseluruhan elemen fungsional pendukung sektor kesehatan. perkembangan sampai saat ini mencakup istilah electronic health record, telemedicine, consumer health informatics, health knowledge managemen, virtual healthcare team, mobile health, healthcare information 
system. e-health dapat dilihat sebagai solusi enterprise atau korporat dalam bidang kesehatan yang melibatkan dukungan seluruh aspek tatanan pemerintahan seperti rumah sakit, puskesmas, dinas kesehatan, industri farmasi, institusi pendidikan tinggi (yang berhubungan dengan kesehatan), poliklinik dan sebagainya.

Jika $e$-health ini di dukung sepenuhnya oleh pihak kependudukan dan administrasi masyarakat dalam lingkup daerah, kota, provinsi, atau nasional maka $e$-health akan menjadi sebuah aplikasi masa depan dalam rangka optimalisasi kesehatan masyarakat yang berkelanjutan yang lebih baik dan efisiensi. [1]

\section{B. Smart City}

Smart city (kota pintar) merupakan pengembangan, penerapan, dan implementasi teknologi digital (TIK) untuk menghubungkan, memonitor dan mengendalikan berbagai sumber daya yang ada dan diaplikasikan pada sebuah wilayah / kota. Smart city mampu meningkatkan kualitas kehidupan, mengurangi biaya dan sumber konsumsi. Smart city membantu meningkatkan interaksi antar kota dan warganya secara efektif serta mendukung pembangunan yang berkelanjutan.[2]

\section{Komponen Fundamental Smart City}
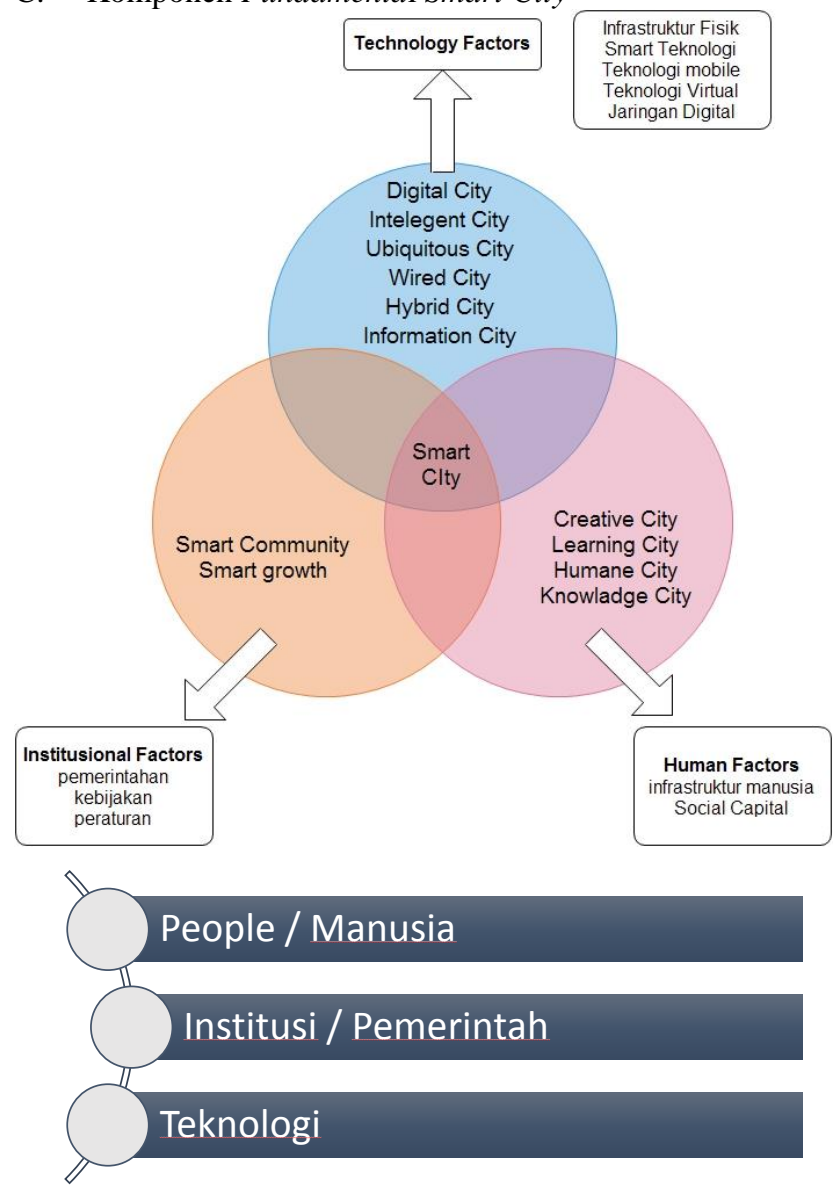

\section{Model Arsitektur}

1. Model

Model adalah pola (contoh, acuan, ragam) dari sesuatu yang akan dibuat atau dihasilkan definisi lain dari model adalah abstraksi dari sistem sebenarnya, dalam gambaran yang lebih sederhana serta mempunyai tingkat presentase yang bersifat menyeluruh, selain itu model adalah abstraksi dari realitas dengan hanya memusatkan perhatian pada beberapa sifat dari kehidupan sebenarnya. Model juga didefinisikan sebagai suatu representasi atau formalisasi dalam bahasa tertentu yang disepakati dari suatu system yang nyata. [6]

2. Arsitektur

Arsitektur lazimnya dimengerti sebagai studi atau pekerjaan merancang bangunan. Sesungguhnya pengertian arsitektur tidak terbatas akan rancangan bangunan saja. Dalam suatu sistem arsitektur adalah cara dimana sebuah sistem yang terdiri dari network, hardware dan software di strukturkan. Arsitektur pada dasarnya menceritakan bagaimana bentuk konstruksi sebuah sistem, bagaimana setiap komponen sistem disusun, dan bagaimana semua aturan dan interface (penghubung sistem) digunakan untuk mengintegrasikan seluruh komponen yang ada tersebut. Arsitektur juga mendefinisikan fungsi, deskripsi dari format data dan prosedur yang digunakan komunikasi diantara setiap node dan workstation [6]

\section{METODOLOGI PENELITIAN}

\section{A. Objek Penelitian}

Objek dari penelitian Ini di dinas kesehatan kota manado serta pelaku-pelaku kesehatan di kota manado seperti rumah sakit, puskesmas, apotik dan klinik di kota manado.

\section{B. Metode Pengumpulan Data}

Metode pengumpulan data yang digunakan pada penelitian ini adalah sebagai berikut :

\section{1) Studi Pustaka}

Pada bagian ini peneliti melakukan kajian pustaka dengan membaca buku-buku dan hasil penelitian dari beberapa peneliti sebelumnya yang memilik hubungan dengan penelitian e-health agar mendapat landasan teori mengenai masalah yang akan diteliti.

\section{2) Kuesioner}

Pada bagian ini peneliti menyebarkan kuesioner kebutuhan pengguna, kuesioner ini disebarkan dengan tujuan untuk menjawab pertanyaan apakah pengguna membutuhkan aplikasi ini atau tidak, dan untuk menentukan fitur-fitur dan sub fitur aplikasi yang akan dirancang nantinya. Penulis menyebarkan kuesioner ke 50 responden yang terdiri atas masyarakat kota manado, Serta Jasa kesehatan yang terkait di kota manado .

\section{3) Wawancara}

Pada bagian ini peneliti melakukan wawancara kepada beberapa narasumber (pegawai rumah sakit, pegawai puskesmas, pegawai apotik, pegawai klinik, dan pegawai di dinas kesehatan kota manado), wawancara yang dilakukan pada bagian ini bertujuan untuk mendapatkan Informasi selengkap lengkapnya mengenai informasi tentang pelayanan kesehatan yang saat ini berjalan di kota manado .

4) Observasi 
Pada bagian Ini peneliti turun langsung lapangan, artinya peneliti melihat langsung proses pelayanan kesehatan kepada masyarakat secara langsung untuk dapat menyimpulkan kendala-kendala yang mungkin terjadi pada saat proses pelayanan pada masyarakat.

\section{Metode Perancangan Model Arsitektur}

Dalam perancangan arsitektur aplikasi $e$ health penulis menggunakan metode EAP (Enterprise Architecture Planning) . penulis menggunakan metode EAP berdasarkan Study literatur dari beberapa Penelitian tentang perancangan arsitektur sistem informasi atau blue print sistem informasi.

D. Metode Enterprise Architecture Planning (EAP)

Adalah merupakan suatu metode yang digunakan untuk membangun sebuah arsitektur informasi. Menurut Steven H. Spewak, Enterprise Architecture Planning atau EAP adalah suatu metode pendekatan perencanaan kualitas data yang berorientasi pada kebutuhan bisnis serta bagaimana cara implementasi dari arsitektur tersebut dilakukan sedemikian rupa dalam usaha untuk mendukung perputaran roda bisnis dan pencapaian isi sistem informasi dan organisasi.

Pada dasarnya EAP bukan merancang bisnis dan arsitekturnya, tetapi mendefinisikan kebutuhan bisnis dan arsitekturnya. Dalam EAP, arsitektur menjelaskan mengenai data, aplikasi dan teknologi yang dibutuhkan untuk mendukung bisnis organisasi. Untuk hal tersebut tadi, Steven H Spewak menyatakan bahwa pemakaian istilah arsitektur terdiri dari arsitektur data, arsitektur aplikasi, dan arsitektur teknologi. Arsitektur disini dimaksudkan layaknya cetak biru, penggambaran, atau model.

Seluruh arsitektur tersebut, dibutuhkan untuk mendukung bisnis yang diselenggarakan oleh enterprise. Kata "mendefinisikan" menurut pengertian Spewak adalah mendefinisikan bisnis dan mendefinisikan arsitektur. Jadi EAP bukan suatu perancangan tetapi pendefinisian. Sedangkan kata "rencana" secara umum adalah membicarakan tentang definisi arsitektur apa yang dibutuhkan, dukungan diartikan sebagai kapan arsitektur tersebut akan diimplementasikan.

Komponen dari metodologi EAP menurut Spewak menggunakan dasar dua lapisan (layer) dari kerangka kerja John Zachman yaitu tahap tinjauan Ballpark dan tinjauan Owner's Hasil EAP adalah cetak biru tingkat tinggi untuk data, aplikasi dan teknologi untuk keseluruhan enterprise yang akan digunakan pada proses perancangan dan penerapan selanjutnya.

Struktur EAP ditunjukkan dalam suatu gambaran komponen yang dikelompokkan menjadi empat lapisan (layer) seperti pada Gambar 2 Masingmasing blok merepresentasikan suatu tahap proses yang berfokus pada bagaimana cara mendefinisikan arsitektur terpadu dan rencana pengembangannya.[8]

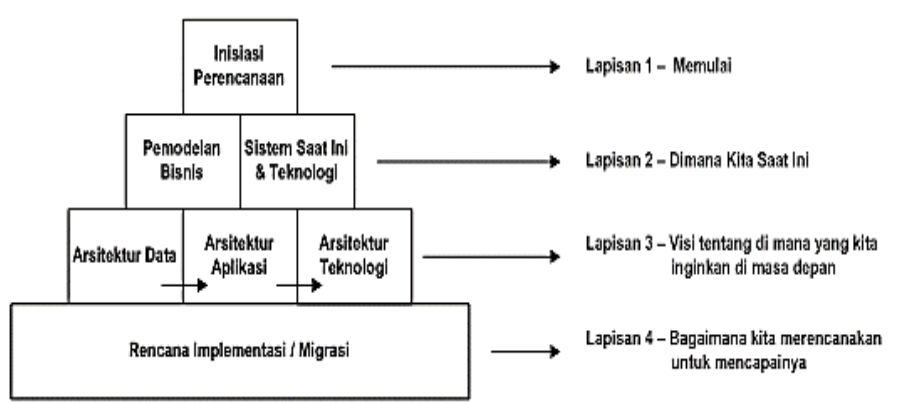

Gambar 2 . Komponen/Tahapan Lapisan EAP

E. Tahapan metode Enterprise Architecture Planning (EAP)

1. Inisiasi Perencanaan

Sesuai dengan matriks langkah pengerjaan EAP diatas, maka tahapan awal yang harus dikerjakan adalah melakukan inisiasi perencanaan, dengan harapan agar proses pembangunan model arsitektur ini dapat terarah dengan sangat baik. Hal ini dilakukan karena pada tahap inilah ditentukannya apa yang akan dilakukan dan apa yang akan digunakan pada tahapan pengerjaan berikut.

Menurut Steven H Spewak, tahapan awal ini menjadi penting, terutama karena pada tahapan inilah ruang lingkup dan perencanaan kegiatan atau rencana kerja didefinisikan. Faktor lain yang menjadi penting adalah, justru pada tahapan inilah dukungan dan komitmen dari unsur manajemen dibutuhkan, yang tidak hanya dalam bentuk verbal, tetapi juga berpengaruh pada personil, anggaran dan waktu.

\section{Pemodelan Bisnis}

Pemodelan bisnis merupakan salah satu tahapan EAP pada lapisan 2, menurut Steven H Spewak, pemodelan bisnis adalah proses identifikasi fungsi-fungsi bisnis, pendeskripsian fungsi dan identifikasi unit organisasi yang melaksanakan setiap fungsi tersebut serta melakukan survey untuk mendapatkan informasi lengkap mengenai bisnis sebagai acuan pemodelan bisnis. Tujuan dari pemodelan bisnis ini adalah untuk menyediakan pengetahuan dasar yang lengkap dan menyeluruh yang dapat digunakan untuk mendefinisikan arsitektur dan rencana implementasinya.

\section{Dokumentasi Struktur Organisasi}

Tahapan ini mempunyai tujuan yaitu mendokumentasikan struktur organisasi dan mengidentifikasi setiap individu dan lokasi yang membentuk suatu fungsi bisnis dalam organisasi. Hasil dari tahapan ini adalah bagan organisasi, daftar posisi dan jabatan, jumlah pekerja dan lokasi pekerja ditempatkan, dokumentasi dari tujuan bisnis, sasaran dan rencana strategi bisnis (boleh dibuat boleh tidak/pilihan).

\section{Identifikasi dan Definisi Fungsi Bisnis}

Tahapan ini bertujuan untuk mendefinisikan struktur dari model bisnis, sedangkan yang harus disampaikan pada tahapan ini adalah laporan mengenai fungsi yang diidentifikasi, dimana setiap fungsi harus memiliki nama, deskripsi singkat, turunan fungsi dan dibentuk dari sedikitnya satu unit organisasi. Fungsi sendiri 
merupakan sekumpulan aksi yang diadakan dalam menjalankan bisnis organisasi. Fungsi dapat didefinisikan sejalan dengan sub fungsinya.

\section{Sistem dan Teknologi Saat Ini}

Tahapan ini mempunyai tujuan yaitu untuk mendokumentasikan dan mendefinisikan seluruh platform teknologi dan sistem yang digunakan oleh enterprise saat ini. Sedangkan yang harus dihasilkan pada fase ini disebut dengan Information Recource Catalog (IRC) yang juga disebut Ensiklopedia Sistem atau inventory system.

\section{Arsitektur Data}

Arsitektur data mengidentifikasi dan mendefinisikan berbagai jenis data utama yang mendukung fungsi bisnis yang terdefinisi pada model bisnis. Arsitektur data adalah salah satu dari tiga arsitektur (arsitektur data, arsitektur aplikasi, arsitektur teknologi) enterprise wide pada Zachman Framework untuk arsitektur sistem informasi. Hal pertama dari ketiga arsitektur tersebut yang didefinisikan terlebi dahulu karena kualitas data adalah produk dasar dan fungsi Sistem Informasi.

Suatu arsitektur data terdiri dari entitas-entitas data, yang masing-masing memiliki atribut dan relasi antar entitas. Dalam pendefinisian arsitektur data dilakukan pendefinisian entitas, yang dapat didefinisikan sebagai orang, tempat, konsep, sesuatu atau bahkan kejadian yang memiliki arti dalam konteks bisnis dan juga mengenai kemungkinan data tersebut didefinisikan. Atribut didefinisikan sebagai karakteristik dari entitas, sedangkan relasi adalah merupakan hubungan antar entitas yang terkait dengan fungsi bisnis.

\section{Arsitektur Aplikasi}

Setelah arsitektur data terdefinisi, selanjutnya disusun suatu arsitektur aplikasi. Arsitektur aplikasi mendefinisikan jenis aplikasi utama yang dibutuhkan untuk mengelola data dan mendukung fungsi bisnis enterprise. Aplikasi yang dimaksud adalah proses pendefinisian aplikasi apa saja yang akan mengelola data dan menyediakan informasi untuk pihak manajemen terhadap fungsi bisnisnya.

\section{Arsitektur Teknologi}

Berdasarkan arsitektur data dan arsitektur aplikasi, selanjutnya disusun suatu arsitektur teknologi yang mendefinisikan jenis teknologi utama (platform) yang dibutuhkan untuk menyediakan lingkungan bagi aplikasi yang mengelola data. Arsitektur teknologi bukan merupakan analisis kebutuhan detil atau rancangan perangkat komputasi enterprise. Hubungkan platform teknologi ke aplikasi dan fungsi bisnis.

\section{Rencana Penerapan}

Rencana penerapan merupakan rencana yang dipersiapkan untuk mengimplementasikan arsitektur enterprise. Dasar pembuatan rencana ini adalah model bisnis, katalog sumber daya informasi dan arsitekturarsitektur yang telah didefinisikan sebelumnya.

Tahapan yang dikerjakan untuk menyusun rencana penerapan adalah :
1. Menyusun urutan/prioritas penerapan sistem. Urutan atau prioritas penerapan aplikasi dapat dinyatakan berdasarkan rantai nilai enterprise. Dengan membuat matriks aplikasi ke entitas data yang telah dioptimalisasi dapat diperoleh suatu urutan aplikasi.

2. Membuat estimasi waktu dan sumber daya berdasarkan kegiatan.

3. Faktor sukses implementasi.

\section{HASIL DAN PEMBAHASAN}

A. Lapisan/ Inisiasi

Tahap ini dilakukan dengan Mengidentifikasi Visi dari Organisasi Dalam Hal ini Visi Dinas Kesehatan Kota manado Yaitu "Manado Sehat menuju kota Ekowisata" dan Kota Manado "Menjadikan Kota Manado Kota cerdas"

B. Pemodelan Bisnis

Pada Tahap ini akan dihimpun pengetahuan mengenai bisnis dan informasi yang digunakan dalam melangsungkan bisnis suatu organisasi. Model bisnis akan menjelaskan dan menggambarkan fungsi-fungsi bisnis organisasi berdasarkan struktur organisasi yang dapat diuraikan menjadi kegiatan-kegiatan yang di lakukan oleh organisasi dalam hal ini jasa kesehatan.

Aktivitas Bisnis dalam Ruang lingkup jasa Kesehatan Meliputi :

1. Proses pendaftaran / registrasi pasien

2. Proses pemeriksaan pasien, rawat jalan/ rawat inap

3. Proses pemesanan obat

4. Proses pengambilan obat

5. Proses pembuatan surat rujukan

Lima proses di atas adalah proses-proses bisnis secara umum yang setiap hari di laksanakan oleh penyedia jasa kesehatan di kota manado, mulai dari rumah sakit, puskesmas, apotik, dan klinik.

C. Perancangan BluePrint

Perancangan blueprint merupakan tahap pendefinisian enterprise asitektur sesuai dengan yang diharapkan. Pada tahap ini didefinisikan arsitektur data, aplikasi, dan teknologi. Sebelum mendefinisikan ketiga arsitektur yang telah disebutkan sebelumnya, terlebih dahulu diidentifikasikan arsitektur target. Hal ini dilakukan untuk memastikan bahwa blueprint yang akan dibangun selaras dengan tujuan dinas kesehatan dan kota manado.

Selain itu arsitektur target yang ditentukan juga di dukung dengan kebutuhan pengguna akan media Informasi secara jelas dan mudah untuk pelayanan kepada masyarakat menjadi lebih baik, di buktikan dengan kuesioner kebutuhan user akan aplikasi yang sudah terisi dalam kuesioner.

Rancangan arsitektur yang di harapkan adalah rancangan arsitektur yang dapat 
mendukung tujuan dalam hal ini jasa kesehatan dan dinas kesehatan kota manado yaitu memberikan pelayanan kesehatan yang lebih baik. di bawah ini adalah rancangan arsitektur yang diharapkan sesuai dengan jawaban responsden pada kuesioner yang telah di bagikan.

1. Memberikan informasi rumah sakit, puskesmas, klinik, dan apotek yang terdaftar di pemerintah kota manado

2. Sistem aplikasi yang mudah di gunakan dan flexible artinya berbasis Android agar dapat dengan mudah di gunakan

3. Untuk rumah sakit, dapat memberikan Informasi ruangan kamar pasien yang kososng

4. Untuk pengambilan nomor antrian di apotik dapat dengan mudah di booking menggunakan aplikasi

5. Dapat memberikan informasi letak setiap posisi penyedia jasa kesehatan (rumah sakit, puskesmas, apotik dan klinik) yang terdaftar dikota manado dll.

\section{Arsitektur Data}

Arsitektur data, di himpun mulai dari rumah sakit, puskesma apotik dan klinik. Dari 4 jasa kesehatan yang menjadi lokasi penelitian, di dapatlah arsitektur datanya dengan entitas-entitas seperti di bawa ini :

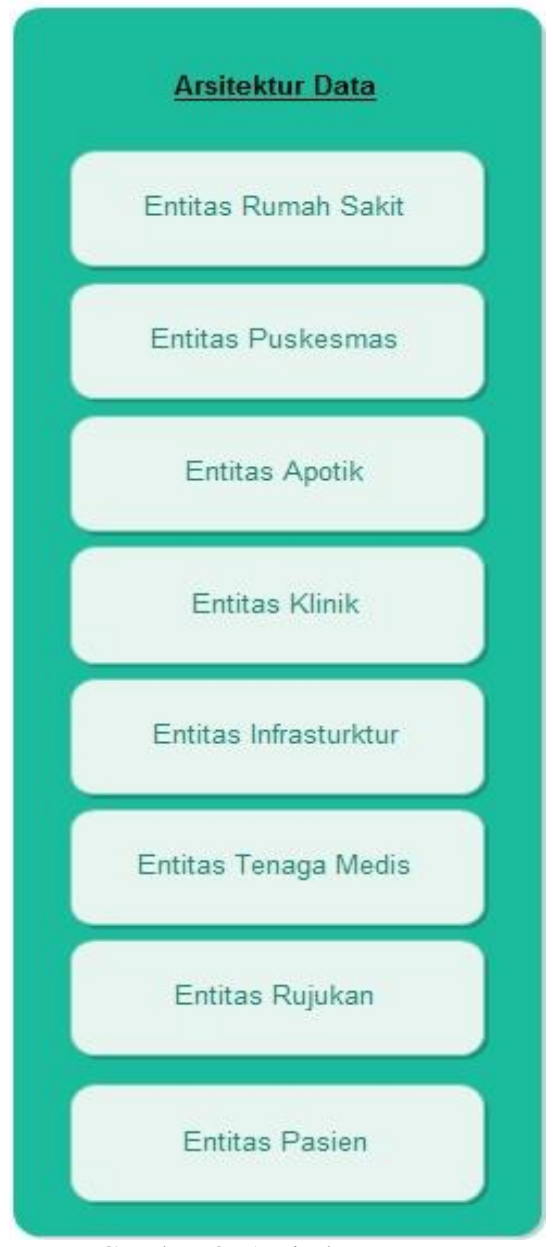

Gambar 3. Arsitektur Data

\section{E. Arsitektur Aplikasi}

Arsitektur aplikasi $e$-health yang akang di bangun adalah bentuk arsitektur aplikasi yang besar, mencakup semua jasa kesehatan yang dibutuhkan di kota manado, dan memiliki sistem integrasi di dalamnya. Dalam pemodelan arsitekturnya yang pertama memodelkan arsitektur aplikasi dalam bentuk diagram yang dapat membantu menjelaskan proses bisnis dan fungsi dari arsitektur aplikasi yang akan di rancang. Dan untuk pemodelan arsitekturnya menggunakan tools UML (Unified Modelling Language). Dalam presentasinya penulis memodelkannya dalam beberapa bentuk diagram yang menjelaskan gambaran dari proses-proses bisnis rancangan aplikasi dari setiap penyedia jasa kesehatan terkait di kota manado.

\section{Diagram UseCase}

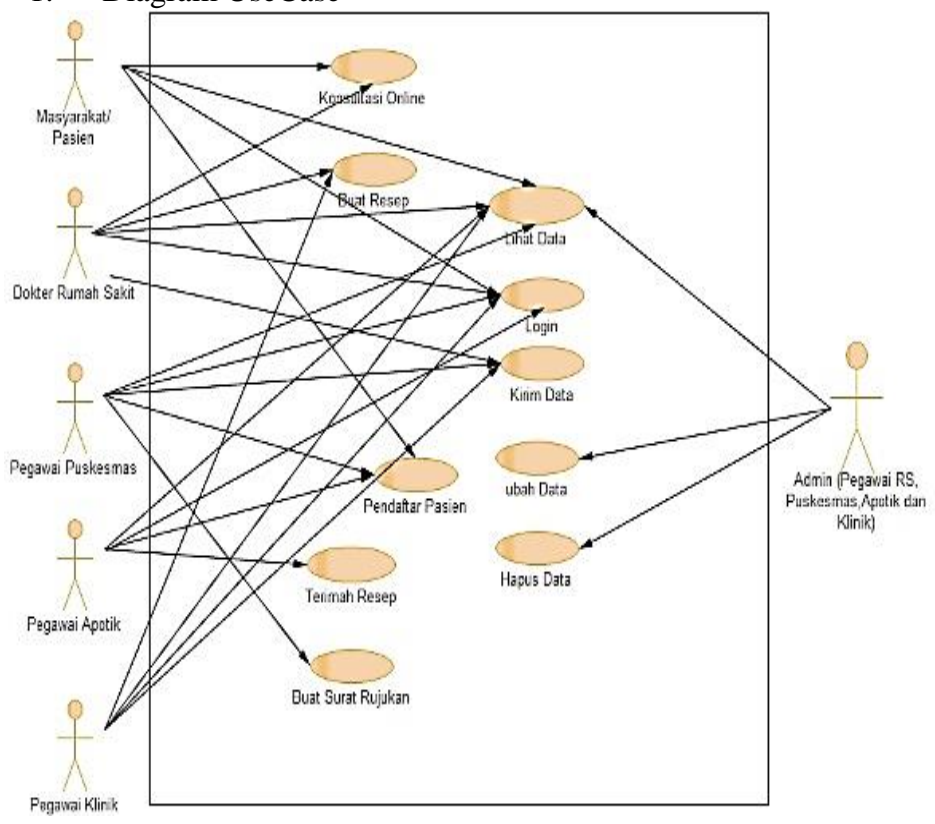

Gambar 4. Usecase Diagram perancangan

Diatas adalah gambaran rancangan dari aplikasi ehealth yang di presentasikan dalam bentuk diagram usecase disitu dijelaskan penyedia jasa yang terhubung dalam satu aplikasi. Mulai dari masyarakat, dokter, pegawai puskesmas, pegawai apotik dan pegawai klinik, dan komponen apa saja yang dapat di akses dari masyarakat, dan penyedia jasa di kota manado. 


\section{Class Diagram}
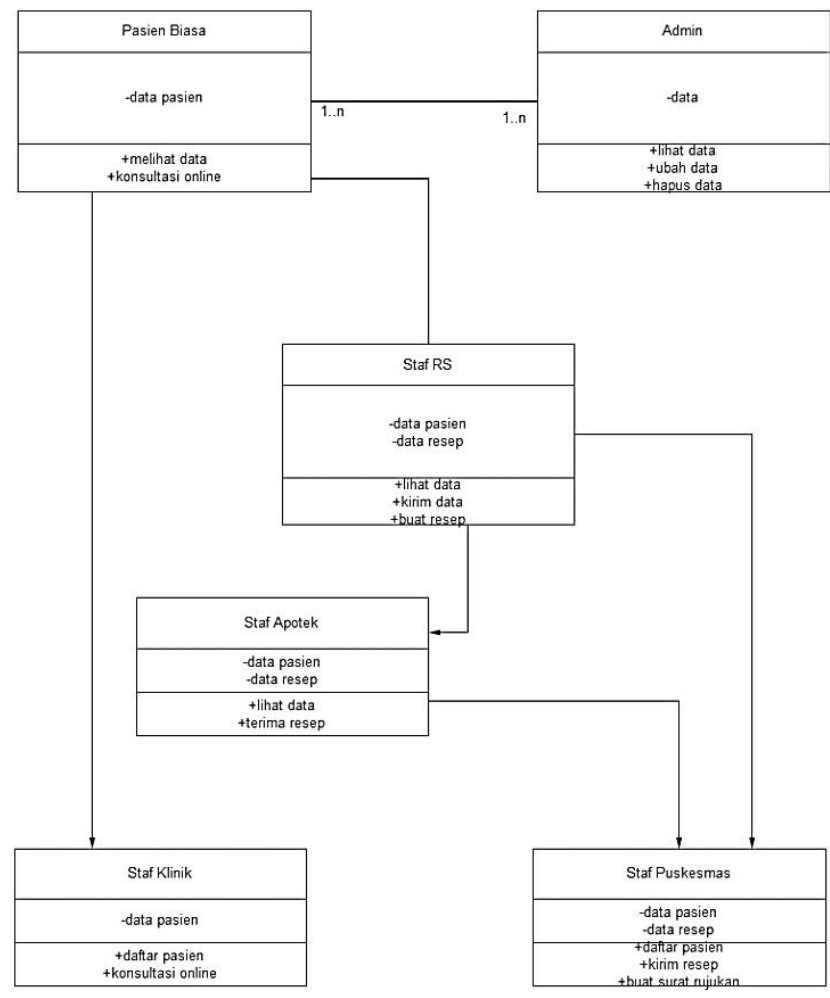

Gambar 5. Class Diagram untuk rancangan Database nya.

3. Diagram activity rumah sakit

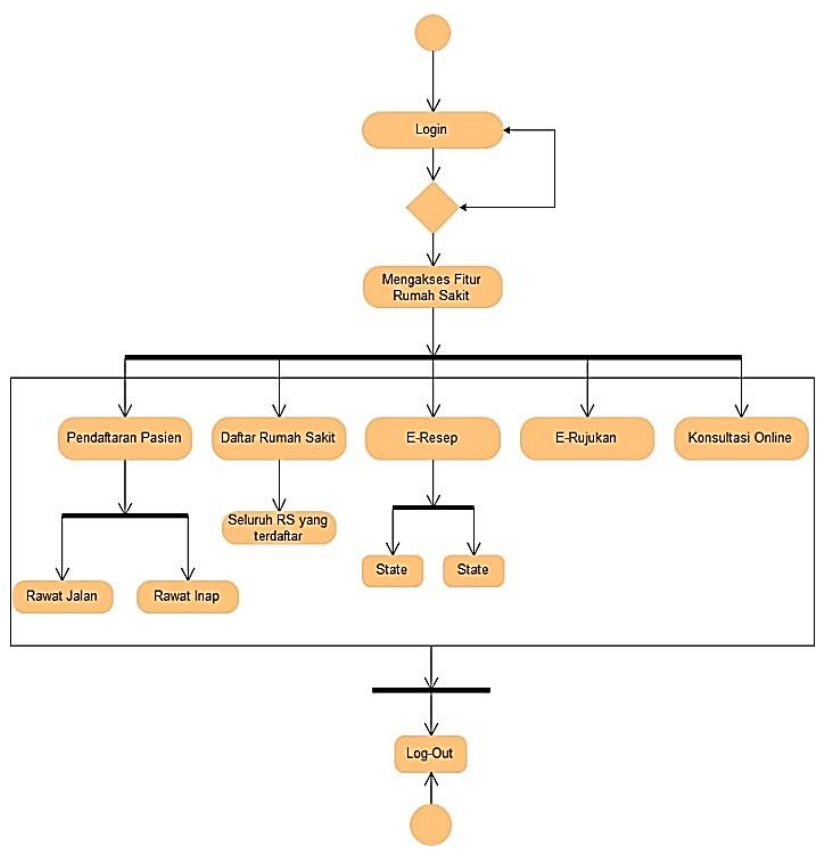

Gambar 6. Diagram ctivity untuk rancangan RS

Gambar diatas adalah gambaran proses bisnis rumah sakit dari aplikasi yang telah di rancang, dan di jabarkan seperti pada gambar 6 mulai dari login sampai pada penggunaan fitur yang tersedia pada rancangan aplikasi.
4. Diagram activity puskesmas

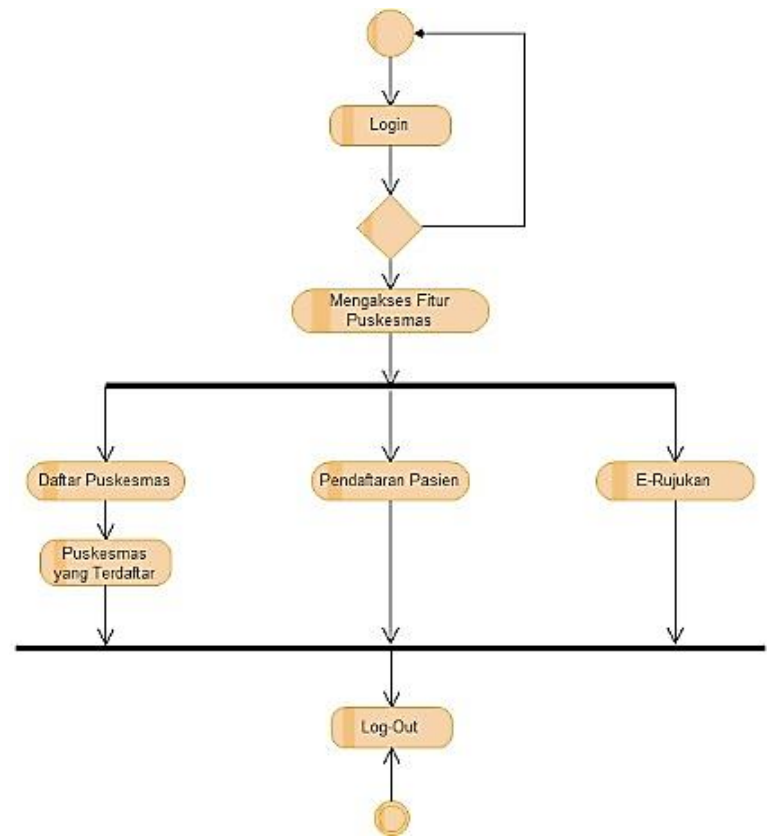

Gambar 7. Diagram activity untuk rancangan puskesmas

Gambar diatas adalah gambaran proses bisnis puskesmas dari aplikasi yang telah di rancang, dan di jabarkan seperti pada gambar 7 mulai dari login sampai pada penggunaan fitur yang tersedia pada rancangan aplikasi.

5. Diagram activity untuk apotik

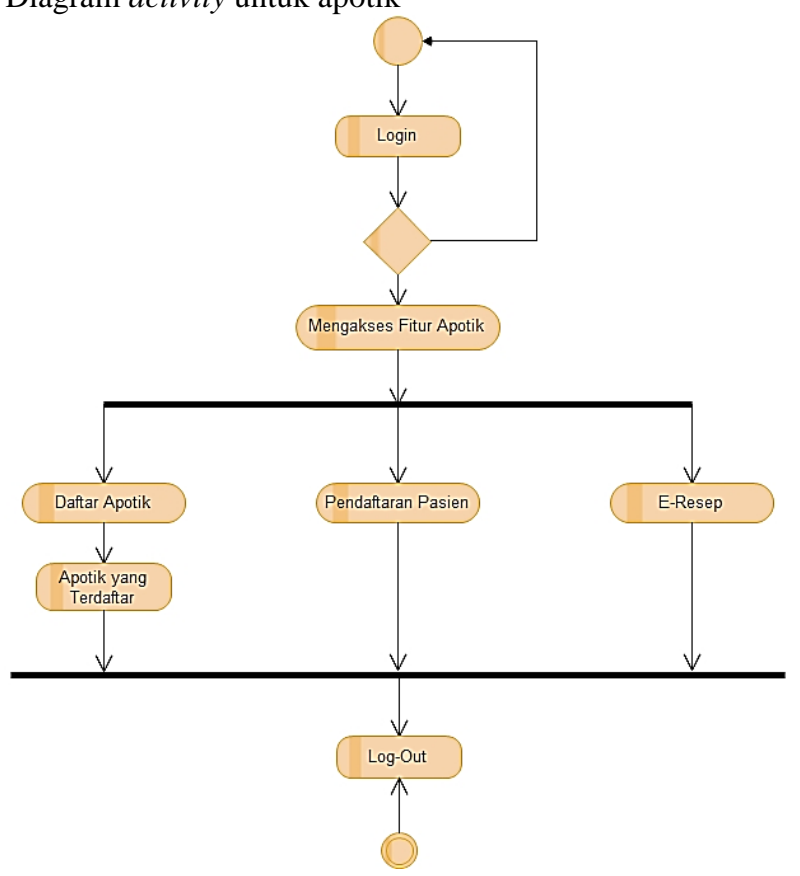

Gambar 8. Diagram activity untuk rancangan apotik

Gambar diatas adalah gambaran proses bisnis apotik dari aplikasi yang telah di rancang, dan di jabarkan seperti pada gambar 8 mulai dari login sampai pada penggunaan fitur yang tersedia pada rancangan aplikasi. 
6. Diagram activity untuk klinik

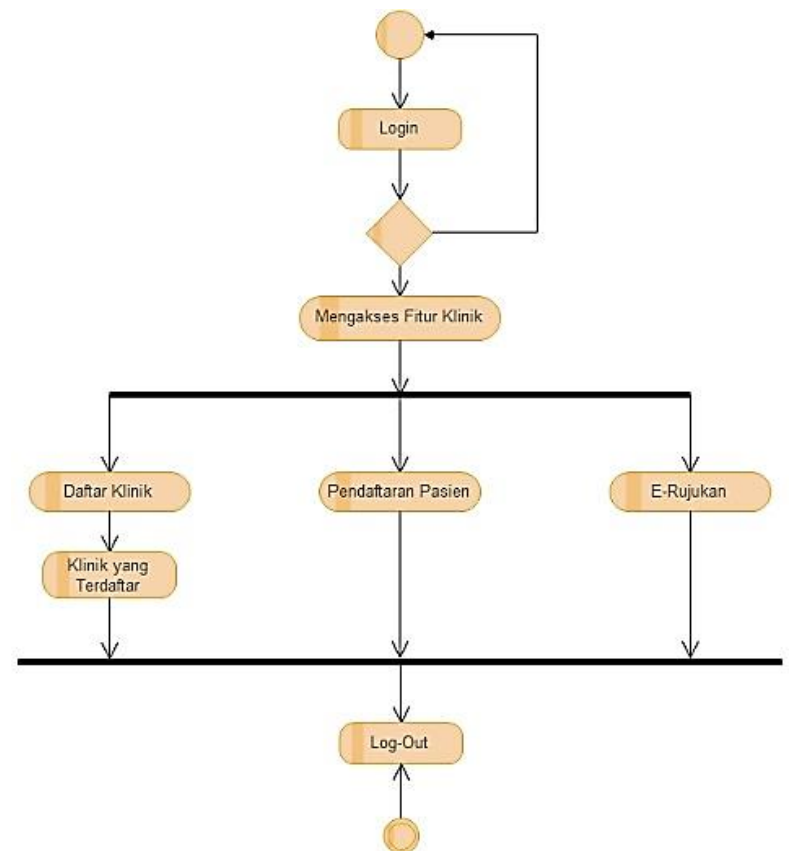

Gambar 9. Diagram activity untuk rancangan klinik

Gambar diatas adalah gambaran proses bisnis klinik dari aplikasi yang telah di rancang, dan di jabarkan seperti pada gambar 9 mulai dari login sampai pada penggunaan fitur yang tersedia pada rancangan aplikasi.

F. Arsitektur Teknologi

Konseptual untuk jaringan dari perancangan arsitektur $e$-health di asumsikan sebagai Berikut :

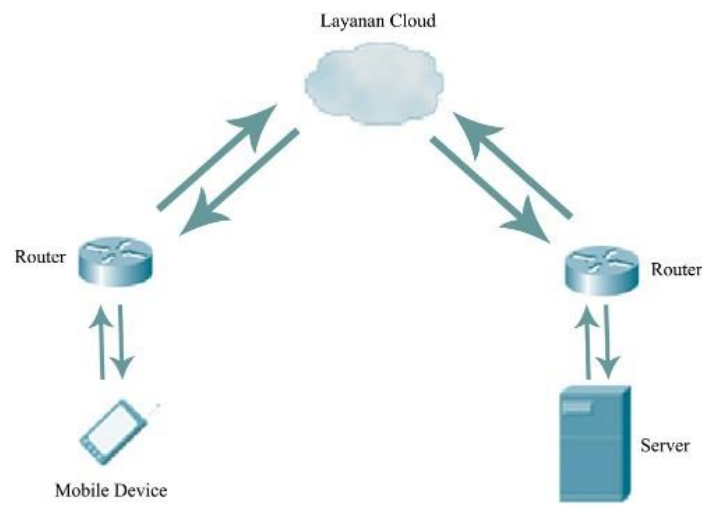

Gambar 10. Arsitektur Jaringan

Fitur perancangan aplikasi e-health kota manado di bawah ini :

1. E-Rumah Sakit

- Daftar rumah sakit kota manado

- Pendaftaran pasien

- E-rujukan

- $\quad$ E-resep

- Konsultasi online
2. E-Puskesmas

- Daftar puskesmas di kota manado

- Pendaftaran pasien

- E-resep

- E-rujukan

3. E-Apotik

- Daftar apotik di kota manado

- Registrasi pengambilan obat

- E-resep

4. E-Klinik

- Daftar klinik di kota manado

- Pendaftaran pasien

\section{PENUTUP}

A. Kesimpulan

Dari penelitian yang dilakukan diperoleh kesimpulan sebagai berikut :

1. Perancangan arsitektur aplikasi e-health kota manado sesuai dengan data primer dan sekunder yang berhasil dikumpulkan dengan menggunakan enterprise arsitecture planning (EAP) sebagai metodologi perancangan.

2. Perancangan arsitektur e-health kota manado sudah sampai pada pemodelannya dan sudah di jelaskan dalam laporan ini.

3. Perancangan arsitktur aplikasi $e$-health ini bisa digunakan sebagai tolak ukur untuk pembangunan aplikasi nya nanti.

B. Saran

Setelah dilakukan penelitian ini, disarankan:

1. Arsitektur yang telah di modelkan agar bisa di lanjutkan pada tahapan-tahapan selanjutnya yaitu pembangunan/implementasi untuk mewujudkan satu sistem $e$-health yang membantu masyarakat.

2. Perancangan yang telah di buat agar bisa di terapkan kembali menggunakan metode atau Framework yang berbeda agar lebih sempurna perancangannya.

\section{DAFTAR PUSTAKA}

[1] Aries Muslim,AB Mutiara,Teddy Oswari,Riyandari Auror,Irdiah Amsawati "standardisasi sistem informasi kesehatan berjenjang open e-health gunadarma information system, mewujudkan layanan kesehatan prima, Universitas Gunadarma 2012.

[2] Oletta E. Mambu, Yaulie D. Y Rindengan, Stanley D. S Karouw "Pengembangan Aplikasi $E$ Report Layanan Masyarakat untuk Manado Smart City” No 1, Manado 2016.

[3] Nur Mas Ammah, Eva Hany Fanida, S.AP., M.AP "penerapan layanan electronic health $(e-$ health) di puskesmas peneleh" kecamatan genteng kota Surabaya" 2016

[4] Edy Kristianto " Pengaruh Teknologi WEB 2.0 terhadap perkembangan E-Health" Jurnal Teknik dan ilmu Komputer (UKRIDA) 2016.

[5] Simatupang, Togar M. 1995, Pemodelan Sistem informasi Klaten, Penerbit Nindita. 
[6] RidhoTaufiq Subagio, : Pemodelan Architecture Enterprise STMIK CIC Cirebon menggunakan Enterprise Architecture Planning" Jurnal Sekolah tinggi manajemen informatika dan Komputer (STMIK) SIS Sirebon. 2012

[7] Roger S.Pressman, Ph.D, 2012 Buku "Rekayasa Perangkat Lunak" Penerbit Andi, Yogyakarta

[8] Nia Ambarsari,NurvitaSetyoutami, 2014 "Perancangan BluePrint Sistem informasi menggunakan metodologi Enterprise architecture Planning (EAP) pada SMAN 3 Surakarta. Jurnal rekayasa Sistem dan Industri

\section{SEKILAS TENTANG PENULIS}

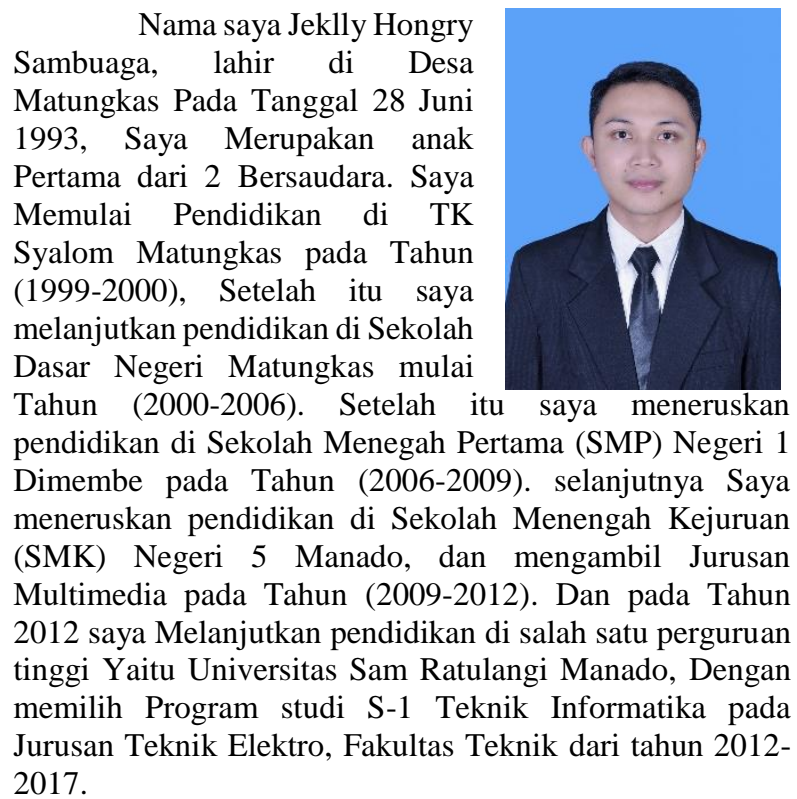

